\title{
Sedimentary architecture models of deepwater turbidite channel systems in the Niger Delta continental slope, West Africa
}

\author{
Liu Li ${ }^{1,2}$, Zhang Tingshan', Zhao Xiaoming', 2*, Wu Shenghe ${ }^{3}$, Hu Jialiang ${ }^{4}$, \\ Wang Xing ${ }^{5}$ and Zhang Yikai ${ }^{5}$ \\ ${ }^{1}$ School of Resource and Environment, Southwest Petroleum University, Chengdu, Sichuan 610500, China \\ ${ }^{2}$ State Key Laboratory of Oil and Gas Reservoir Geology and Exploitation, Chengdu University of Technology, Chengdu, \\ Sichuan 610500, China \\ ${ }^{3}$ College of Geosciences, China University of Petroleum, Beijing 102249, China \\ ${ }^{4}$ The Petroleum Institute, Abu Dhabi 2533, The United Arab Emirates \\ ${ }^{5}$ Research Institute, China National Offshore Oil Corp, Beijing 100027, China
}

(C) China University of Petroleum (Beijing) and Springer-Verlag Berlin Heidelberg 2013

\begin{abstract}
This paper studied an architecture model of turbidite channel systems based on the shallowlayer high resolution 3D seismic information in the deepwater area in the Niger Delta continental slope, West Africa as a prototype model. Different types of channel systems were identified and the corresponding architecture models were established. The controlling factors, evaluation criteria and spatial distribution of different channel systems were analyzed. This study shows that turbidite channel systems of West Africa could be classified into three types; confined, semi-confined and unconfined, according to the condition of canyon and the levees on both sides. On one hand, along the transport direction, channel system evolves from confined to unconfined. Within channel systems, channel complexes, including two types of incised and enveloped, are the most important reservoir bodies. On the other hand, there is a channel complex evolution from incised to enveloped vertically. The geological factors exert impacts of different levels on the architecture of the turbidite channels in different sedimentary systems or even within the same system.
\end{abstract}

Key words: Niger Delta continental slope, deepwater deposits, turbidite channel systems, architecture models

\section{Introduction}

Deepwater sedimentation is an important factor in current oil and gas exploration (Chen, 2003; Jiang et al, 2008; Chen, 2011; Zhu et al, 2012; Wu et al, 2009). However, the study of its reservoir architecture model has lagged behind that of fluvial, alluvial and deltaic deposits (Slatt, 2006). The reasons are as follows. First, deepwater depositional systems cannot be easily observed in the modern environment; contrary to non-marine sedimentation, they deposit in the marine environment where water depth usually exceeds $300 \mathrm{~m}$, as a consequence, it is difficult to use remote-observation techniques to study their sedimentary patterns. Second, outcrops of deepwater sedimentation can barely provide information on a fraction of the entire system; submarine deposits are characterized by large scale of generally several kilometers or even more than ten kilometers in width. The

*Corresponding author. email: zhxim98@163.com

Received August 26, 2012
Amazon fan for example, has a canyon breadth of up to 15 kilometers (Shepard and Emery, 1973; Hesse et al, 2001) with thickness from tens to hundreds meters. In short, deepwater sedimentation belongs to large scale units; however, outcrops can only provide limited architectural information of small scale units. Consequently, it is difficult to characterize an entire system only using information from outcrops.

Therefore, 2D or 3D seismic-reflection technologies are needed to characterize the architecture model of turbidite channel systems. Especially in recent years, there has been rapid development of seismic acquisition and processing technologies leading to a continuous improvement in the vertical resolution of seismic data. For this reason, many scholars have begun to apply seismic information to describe and measure deepwater turbidite channels and there have been a series of achievements (Corbeanu et al, 2001; Viana et al, 2003; Samuel et al, 2003; Droz et al, 2003; Saller et al, 2004; Wood and Mize-Spansky, 2009; Shao et al, 2007; Dong et al, 2008; Chen et al, 2012). 
However, previous and present studies of deepwater architecture models mainly focused on middle and small scale sedimentary units, such as channel complexes and single channels (Kolla et al, 2001; Beaubouef, 2004; Labourdette and Jones, 2007; Pyles et al, 2010), and there are few studies of large scale features, such as channel systems (Martin et al, 2011). In addition, systematic and hierarchical studies are greatly needed. We studied the turbidite channel architecture model within passive basins based on shallow-layer high resolution 3D seismic information in deepwater Niger Delta of West Africa as a prototype model. Different types of channel systems were identified and the corresponding architecture models were established and the controlling factors and spatial distribution of different channel systems were analyzed. This study may provide theoretical foundation, from a geological perspective, for the evaluation and development of deepwater reservoirs.

\section{Geological background}

The study area covers $350 \mathrm{~km}^{2}$ and is situated in the Niger Delta of West Africa, roughly $200 \mathrm{~km}$ to the south of Port Harcourt with water depths of about 1,300-1,500 m (Fig. 1). The source area is the Niger River system to the north (Lü et al, 2008). This subsection provides a brief introduction to the background of tectonics, depositional settings and stratigraphy.

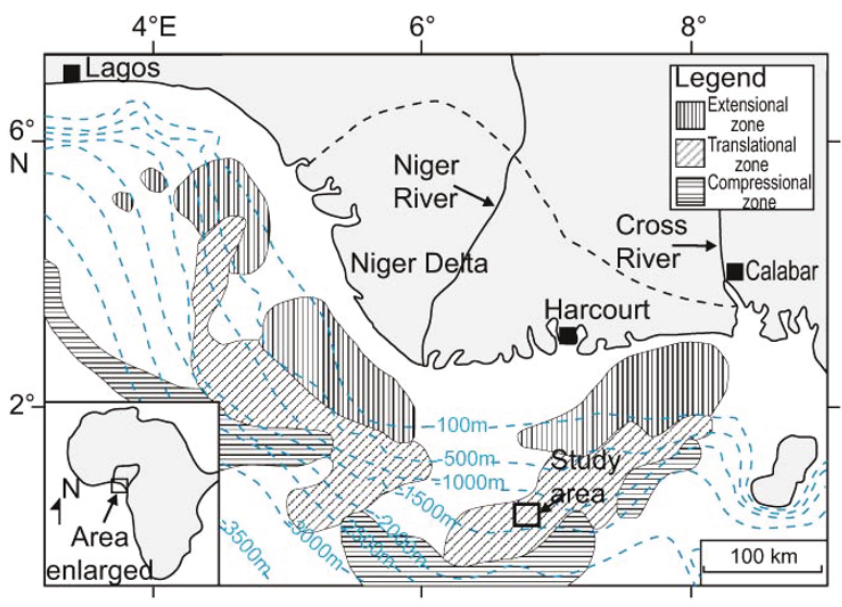

Fig. 1 The Niger Delta continental margin showing bathymetry, zones of gravity tectonic style (Modified from Adeogba et al, 2005)

\subsection{Tectonic setting}

The Niger Delta Basin developed in the Early Cretaceous and is a passive continental margin basin whose evolution can be divided into rifting and drifting phases. Development of this basin is attributed to the collapse of Gondwanaland and the splitting of the south and equatorial Atlantic (Karner et al, 1997).

Since the Eocene, long-term regression had prompted the formation of the present Niger Delta, and during this progradational process, the Niger Delta, affected by gravity, formed a series of tectonic zones. Damuth (1994) divided the delta into three major zones; from north to south these are 1) the upper extensional zone of listric growth faults beneath the outer shelf; 2) the translational zone of diapirs and shale ridges beneath the upper slope; and 3) the lower compressional zone of imbricate thrust structures (toe thrusts) beneath the lower slope and doming area. The study area lies within the translational zone between extensional and compressional zones (Cohen and McClay, 1996; Corredor et al, 2005), and belongs to the diaper-tectonic zone (Fig. 1).

\subsection{Depositional setting and stratigraphy}

The stratigraphy succession of Niger Delta mainly consists of three regressive lithostratigraphic units, as shown in Fig. 2. From the oldest to the youngest these are the Akata, Agbada, and Benin formations (Short and Stauble, 1967). The Akata Formation of marine deposits, whose lithology is predominantly dark grey shale with turbidite or slope canyon sediments, provides the most important source rocks in the Niger Delta Basin, and its thickness is 2,000 $\mathrm{m}$ to 7,000 m (Doust and Omatsola, 1990). The Agbada Formation of fluvial delta and marine facies, mainly comprised of sandstone interbedded with mudstone and marine shale, is the major oil producing interval in weakly cemented sandstone accumulated from Eocene until Quaternary with a thickness of over 3,500 m (Corredor et al, 2005). The Benin Formation, whose lithology is mainly sandstone with thin mudstone or shale, represents a set of continental delta plain sediments. The possible microfacies of sand bodies include mouth bar, branch channel and levee. This formation was deposited mainly in continental and neritic environments from the Late Eocene to Holocene, and its thickness is up to 2,000 m (Corredor et al, 2005).

The target interval is located in the Agbada Formation. Lü et al (2008), from the perspective of sequence stratigraphy, pointed that the study area had been in a deepwater sedimentary environment, although there were several obvious regression events. In addition, it is likely to have gravity slumping and submarine turbidites since the study area lies near the lower slope. Actually, seismic sedimentology analysis shows that deepwater gravity flow which deposits under LST (lowstand systems tract) is the main sedimentary system for the study area, and the facies predominately consist of mass transport deposits and turbidite channels, etc (Li et al, 2008).

\section{Seismic database and methodology}

The data set used for this research is a conventional 3D seismic volume with sampling interval of $3 \mathrm{~ms}$ and line spacing of $12.5 \mathrm{~m}$ in both crossline and inline directions. The study interval is from the seafloor to the fourth condensed section. There are four major sedimentary cycles in the interval with an extensive and laterally continuous reflection at the top of each one (Fig. 3(a)). This interval ranges in thickness (two way travel time, TWT) from $0.6 \mathrm{~s}$ to $1.5 \mathrm{~s}$, and spectrum analysis shows that it has a frequency bandwidth from $15 \mathrm{~Hz}$ to $90 \mathrm{~Hz}$ with a dominant frequency of $70 \mathrm{~Hz}$ (Fig. 3(a)). If we take the interval velocity at $1,900 \mathrm{~m} / \mathrm{s}$, the resolution of thickness is approximately $6 \mathrm{~m}$, which can basically meet the need of architecture characterization of 


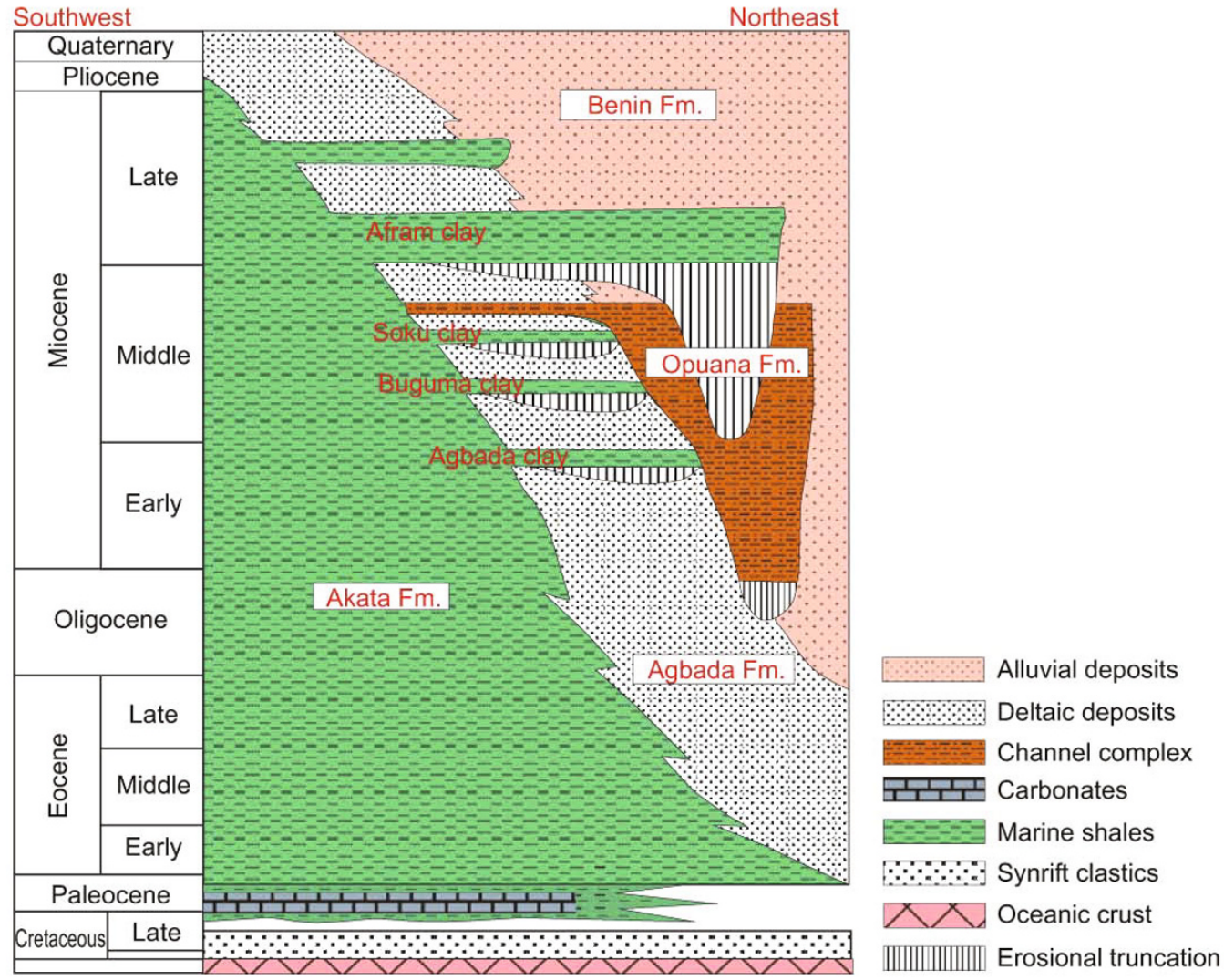

Fig. 2 Schematic diagram of the regional stratigraphy of the Niger Delta in the outer fold and thrust belt (After Corredor et al, 2005)

different single channel bodies.

Because insufficient borehole data have been collected in the study interval to calibrate seismic interpretation with lithology, sedimentary types are inferred from the external morphology, the internal amplitude characteristics of seismic facies, and stratigraphic position as well as indirectly by analogy with seismic and sedimentary facies interpretation from other areas where borehole data are available (Weimer, 1989; Beaubouef and Friedmann, 2000; Deptuck et al, 2003; Moscardelli et al, 2006; Xu et al, 2009). Three types of sedimentary facies, including massive transport, channel system and deepwater drape deposits, are interpreted. Massive transported deposits, with weak event continuity, are mainly characterized by massive and tumble reflection texture with dusky or translucent amplitudes (Fig. 3(b)). Commonly, they are preserved with large thickness and lateral extension as a result of sediment slumping from shelf margins or slopes in LST during regression. Channel deposits, with $\mathrm{V}$-shape or U-shape in seismic sections, are predominantly characterized by rough or imbricated reflection texture of poor-moderate continuity and moderate-bright (strong) amplitudes (Fig. 3(b)). Sometimes, on sides of channels, there are wedge-shape levees developed with reflectors of high-continuity and amplitudes of weak to moderate-bright (Fig. 3(b)). Theoretically, channels have diverse origins with complex internal patterns and usually exert strong influence of incision on the underlying sediments. This will be covered in this paper. Submarine drape facies are characterized by parallel seismic reflections with highly continuous events and moderate-bright amplitudes (Fig. 3(b)). In most cases they have conformable contacts with the overlying and the underlying strata, but sometimes they slightly onlap the syndepositional terrain at the bottom suggesting a homogeneous sedimentation with no contribution from the undulating ground.

\section{Results and observation}

Reservoir architectures of different depositional sets even within the same deep-water turbidite channel system show diversity to some extent, influenced by different levels of incisional ability, which indicates that channel systems have diverse types and that one specific channel system corresponds to a unique evolutionary process.

\subsection{Channel system types}

Based on seismic facies features from the shallow seismic data, channel systems, with different geomorphologic features, can be classified into three types; confined, semi-confined and unconfined. Confined channel systems, with V/U shape in seismic sections, develop an obvious incised surface (Fig. 4(a)), which is the boundary of large scale incised valleys (or canyons). Although semi-confined channel systems also develop an obvious incised surface, compared with confined ones, they have wedge seismic facies developed on both sides (Fig. 4(b)), which correspond to large-scale levee deposits. They are generally seagull morphology in seismic sections (as the sloping levees at the sides of the channels look like 


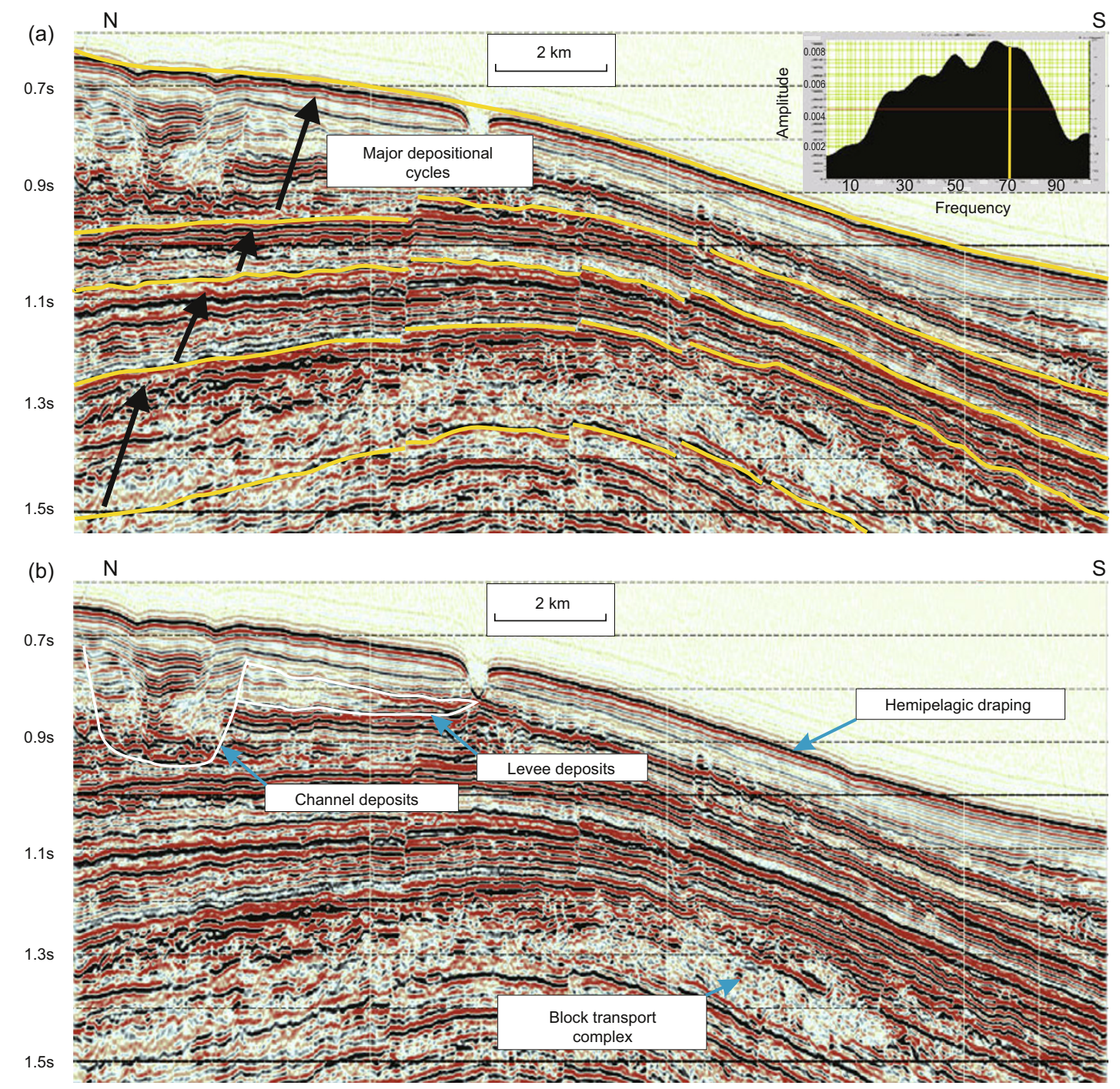

Fig. 3 (a) The major depositional cycles and the frequency dependence of the shallow seismic data. (b) The external morphology and the internal amplitude characteristics of seismic facies

seagull's wings). Within unconfined channel systems, the most important feature is that no large-scale incised valley is developed as an obvious boundary (Fig. 4(c)) and they have hummocky morphology in seismic sections.

Channel complexes develop in the channel system. As shown in Fig. 5, a channel complex can be classified into two categories on the basis of the external morphology and the internal amplitude characteristics of seismic facies. One is the incised channel complex developed in circumstances of strong erosion with characteristic small-scale incised valleys. The break points of seismic events mark the complex boundary. An incised valley contains multiple single channels of hummocky-parallel reflections with strong amplitude as seismic features. The other category is the enveloped channel complex, developed in conditions of weak erosion, with no incised submarine canyons but with a boundary as an envelope-line of multiple single channels, which have an imbricate reflection configuration on seismic profiles. Incised and enveloped channel complexes could develop in the same channel system but they often have different proportions within different channel systems of different sediment energies.

According to topography and the corresponding types of the inner channel complexes, channel systems can be further classified into three types of confined channel system, semiconfined channel system and unconfined channel system, with two subgroups for each of them (Table 1). The nomenclature of each subgroup follows the name of channel system and takes the type of inner channel complexes into account. A confined channel system, for example, is called confined incised channel system when incised channel complexes dominate, or on the other hand, a confined enveloped channel system when enveloped channel complexes dominate.

\subsection{Architecture patterns of different channel systems}

A distinctive architecture corresponds to a unique channel system. Based on the seismic response features, architecture models for different channel systems (Fig. 6) have been established, as described below.

A confined channel system is characterized by large scale incised valley with negligible or no natural levees. According 

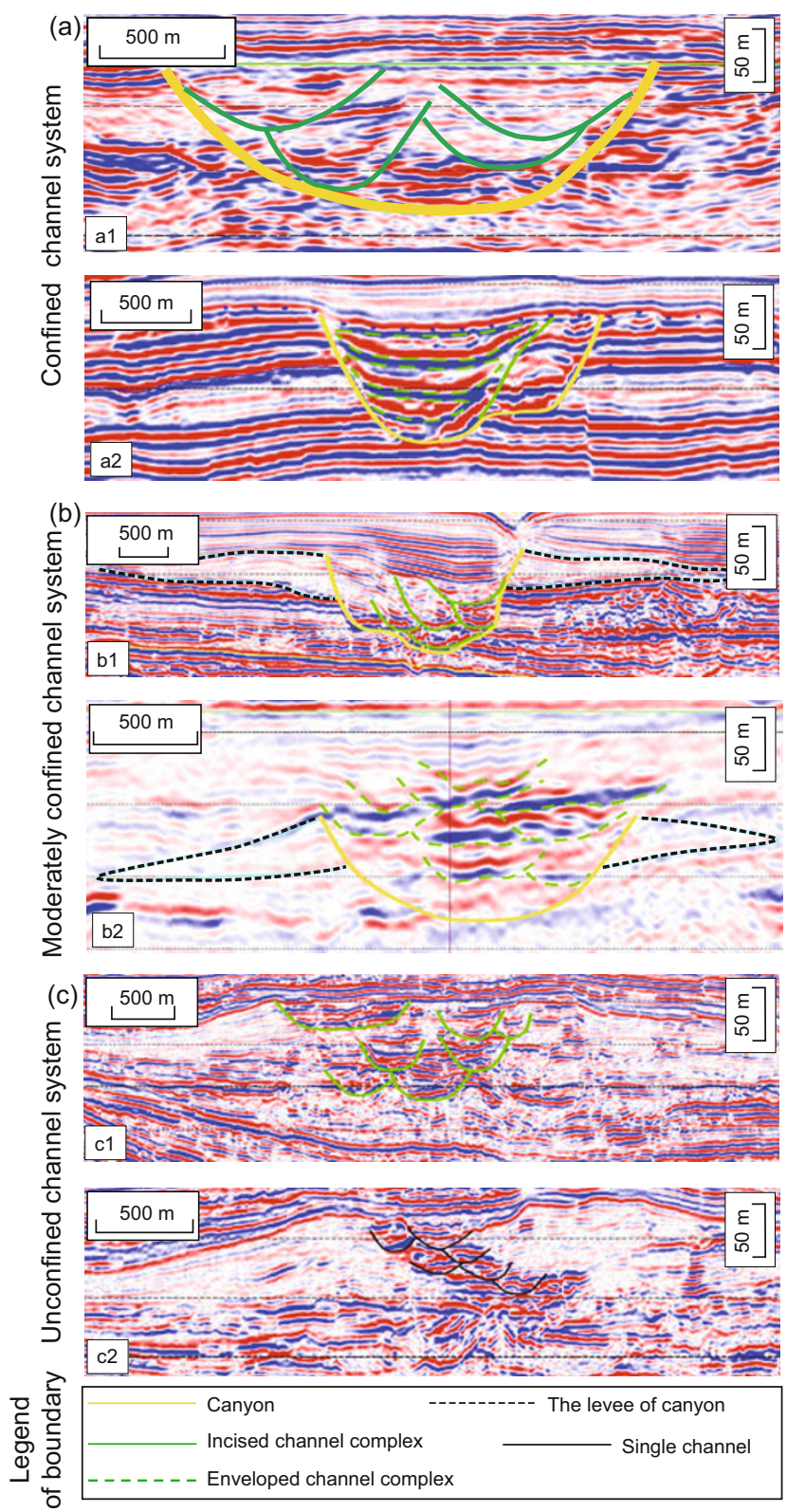

Fig. 4 Seismic profile showing the three major channel systems identified in the study area based on the internal configuration and texture and external geometry of seismic reflections to different patterns of internal channel complexes, confined channel systems can be further classified into incised and enveloped subgroups. In confined incised channel systems, incised valleys, commonly, are filled with a large number of massive loads, collapsed and passing sediments with local incised channel complexes. On the other hand, confined enveloped channel systems are dominated by enveloped channel complexes with local distribution of collapsed, passing and draping sediments.

Incised valleys could also develop in semi-confined channel systems, but compared with those in confined systems, migration of these incised valleys is probably much more common and there are large scale natural levees (incised-valley natural levees) on both sides. The incisedvalley natural levees have a wedge-shape in profile, taking up two thirds of the width of the entire channel system. These large-scale natural levees also have two categories of nearchannel levees and off-channel levees according to their distances from the channels. The near-channel levees are characterized by thin interbedded sands and shales, while the off-channel levees are dominated by mud with locally thin sand layers. On the other hand, semi-confined channel systems can be classified into two subgroups of incised and enveloped based on channel-complex internal patterns. The channel complexes in semi-confined incised channel systems are basically filled with collapsed sediments while the channel complexes within semi-confined enveloped channel systems are mainly filled with relative fine sediments from draping and passing. This kind of channel systems could also be classified into two categories of strongly-confinedchannels and weakly-confined-channels. The typical feature of the former is that enveloped channel complexes develop solely in the incised valleys, and the latter is that enveloped channel complexes not only develop in the incised valleys but also cover the top of incised valleys.

No incised valley exists in unconfined channel systems, which differs from confined and semi-confined systems. According to the type of internal channel complexes, an unconfined channel system can also be classified into two categories of incised channel system and enveloped channel system. The vertical and lateral migration of incised channel
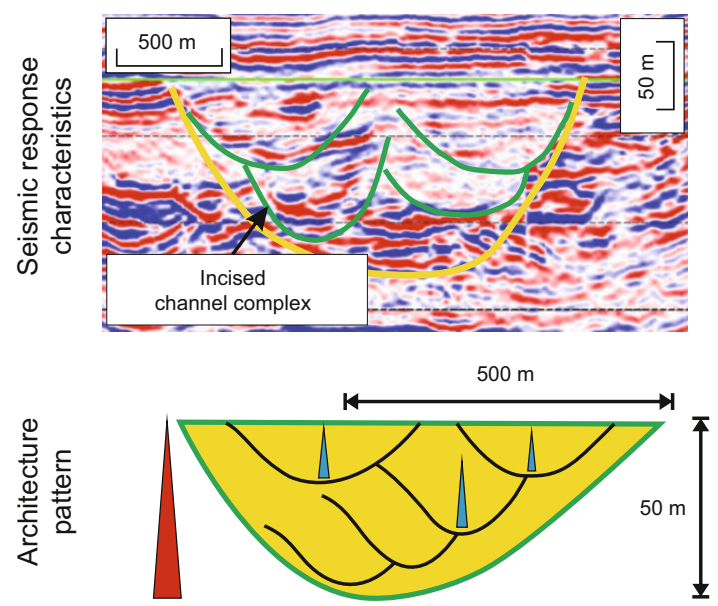
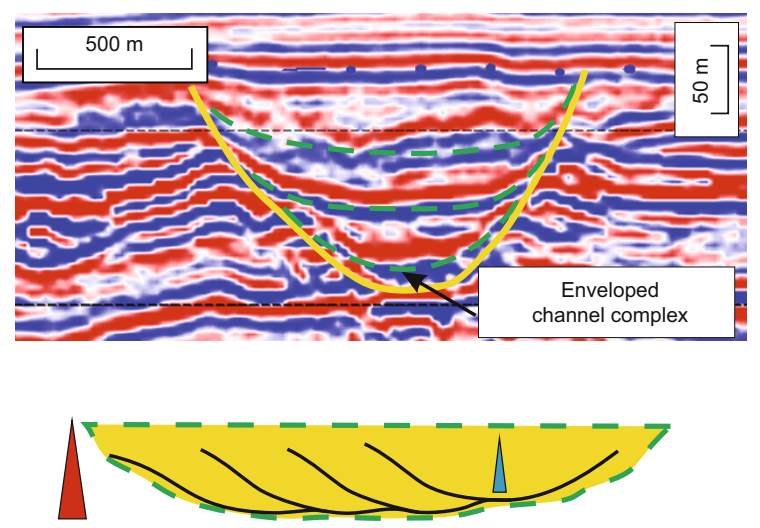

Fig. 5 Interpreted (upper) seismic profile showing the architecture patterns of deep-water channel complexes (lower) 
Table 1 Classification schedule of channel systems in the study area in the Niger Delta Basin, West Africa

\begin{tabular}{|c|c|c|c|c|}
\hline Channel system types & Geomorphologic features & Channel complex types & Channel system subtypes & $\begin{array}{c}\text { Characteristics } \\
\text { of seismic reflection }\end{array}$ \\
\hline \multirow{2}{*}{ Confined channel system } & \multirow{2}{*}{ V-shaped or U-shaped } & Incised channel complex & Confined incised channel system & Hummocky/parallel \\
\hline & & Enveloped channel complex & Confined enveloped channel system & Imbricate \\
\hline \multirow{2}{*}{$\begin{array}{l}\text { Semi-confined } \\
\text { channel system }\end{array}$} & \multirow{2}{*}{ Seagull morphology } & Incised channel complex & $\begin{array}{c}\text { Semi-confined } \\
\text { incised channel system }\end{array}$ & Hummocky/parallel \\
\hline & & Enveloped channel complex & $\begin{array}{c}\text { Semi-confined } \\
\text { enveloped channel system }\end{array}$ & Imbricate \\
\hline \multirow[b]{2}{*}{ Unconfined channel system } & \multirow[b]{2}{*}{ Hummocky morphology } & Incised channel complex & Unconfined incised channel system & Hummocky/parallel \\
\hline & & Enveloped channel complex & $\begin{array}{l}\text { Unconfined enveloped } \\
\text { channel system }\end{array}$ & Imbricate \\
\hline
\end{tabular}

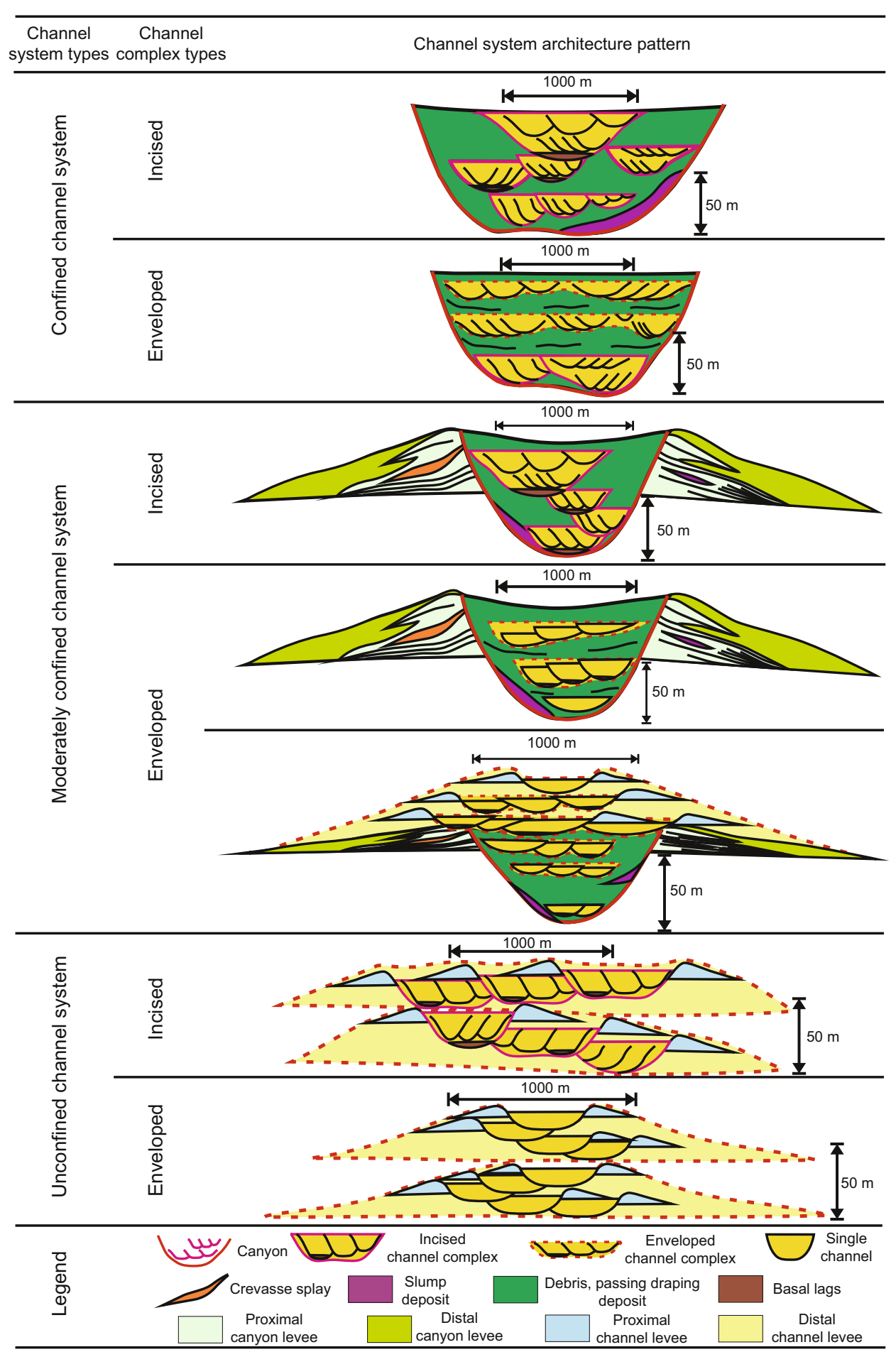

Fig. 6 Schematics showing the architecture models of different channel systems in the study area of Niger Delta Basin, West Africa 
complexes contribute to the development of incised channel systems, while enveloped channel systems are derived from vertical and lateral migration of a single channel. In this kind of channel system, small scale natural levees, referred as channel levees, are developed along both sides of the channel complexes. This kind of channel levees could also be classified into two categories of near-channel and off-channel based on the distance from channels.

\section{Discussion}

\subsection{Analysis of controlling factors}

The types and features of deepwater detrital deposition are results of the interaction of a series of auto-cycles and hetero-cycles (Emery and Myers, 1996; Wang et al, 2012). The controlling factors include sea-level fluctuation, regional tectonics, sediment types, the rate of sediment supply as well as the type of transportation (Stow et al, 1996; Stow and Johansson, 2000; Piper and Normark, 2001; Wang et al, 2007; Fugelli and Olsen, 2007; Li et al, 2012; 2010). In addition, frequent events such as hurricanes and earthquakes with high energy could also have triggered the transportation of debris grains, down shelf and slope, to form deep-water sediments (Shanmugam, 2008).

It is hard to compare the importance of each of these controlling factors. However, it is certain the different erosive abilities of sediments determine the infilling patterns within different channel systems or within the same channel system, which could be reflected in the kinetic energy and mass functions as follows,

$$
\begin{aligned}
& E=m \times v \\
& m=\rho \times V
\end{aligned}
$$

where, $E$ is the energy of sediment, $m$ is loading mass, $v$ is the flow rate of load, $\rho$ is the density of load, $V$ is the volume of load.

According to the functions above, the physical parameters that control the erosive ability of sediments include the density, volume and flow rate of the load, which are the result of a series of geological factors (Table 2). In terms of density, it is mainly controlled by the grain size of the sediments, which itself is determined by distance to the provenance and the type of source rocks. Normally, high density corresponds to coarse loads. In terms of load volume, it is essentially determined by the amount of sediment supply, the influencing factors of which include sea-level fluctuation, geological events namely tsunamis, hurricanes and earthquakes, as well as climatic changes in sediment sources. In terms of flow rate, it is mainly controlled by topography, distance to the source area and the width-depth ratio. In most situations, flow rate increases as the distance from the source decreases, slope increases and width-depth ratio decreases.

These geological factors exert impacts at different levels on the architecture of the turbidite channels in different sedimentary systems or even within the same system. In different turbidite channel systems, the source area plays a more important role in reservoir architectures than eustasy, slope, and climate. For example, confined channel systems are more likely to develop with source areas rich in gravels and sands, on the contrary, semi-confined and unconfined channel systems tend to develop with source areas rich in sand-mud mixtures or mud. An individual channel system's type is controlled by interaction of various geological factors. However, primary factors play the most important role. For instance, sediment flow rate is high in steep-slope areas with intense erosion resulting in confined and semi-confined channel systems, while semi-confined and unconfined channel systems mainly develop in gentle-slope areas. Similarly, all

\begin{tabular}{|c|c|c|c|c|}
\hline & \multicolumn{2}{|c|}{ Physical parameters } & \multirow[t]{2}{*}{$\begin{array}{l}\text { Sedimentary } \\
\text { factors }\end{array}$} & \multirow[b]{2}{*}{ Distance to the source area } \\
\hline \multirow{8}{*}{ Sediment energy } & \multirow{5}{*}{ Load quality } & \multirow[b]{2}{*}{ Load density } & & \\
\hline & & & Grain size & $\begin{array}{c}\text { Source types, for example, rich conglomerate, rich sand, mixture of sand and mud, } \\
\text { rich mud }\end{array}$ \\
\hline & & \multirow{3}{*}{ Load volume } & \multirow{3}{*}{ Sediment supply } & $\begin{array}{l}\text { Sea-level fluctuation, for example, lowstand system tract, transgressive system tract, } \\
\text { highstand system tract }\end{array}$ \\
\hline & & & & Geological events, for example, tsunami, hurricane, earthquake \\
\hline & & & & Climate changes in the source area, for example, drought, wet \\
\hline & \multirow{3}{*}{\multicolumn{2}{|c|}{ Load flow rate }} & & Topography, for example, steep slope area, gentle slope area \\
\hline & & & & Distance to the source area \\
\hline & & & & Width-depth ratio \\
\hline
\end{tabular}

Table 2 Factors affecting erosive abilities of different sediments

kinds of channel systems could exist in a lowstand system tract during regression, but theoretically, turbidite systems would not develop in highstand system tracts without influences from other geological factors.

\subsection{Spacing evolution trend}

Channel systems possess spatial evolutionary trends in spite of the fact that they are controlled by multiple factors. In short, channel systems evolve laterally and channel complexes evolve vertically within channel systems.

In the plane, channel systems influenced by the different erosive ability of sediment gravity flows along the transporting direction could show some kind of evolution (Fig. 7). Near source, sediments are of large grain-size, high flow 
rate and strong erosive ability at the proximal upper slope, where canyons or large scale incised valleys could evolve into confined channel systems. Sediment transportation is the major process in this kind of channel system, resulting in large amounts of debris flow, turbidite and collapsed sediments with some locally developed straight or braided channels. On the middle slope, sedimentation gradually supersedes erosion as sediments become finer and flow rates slow down. In this situation, the most common channel system is a semiconfined channel system in which both incised and enveloped channel complexes are developed with some debris, collapsed and passing sediments infilling and large-scale natural levees on both sides. Noticeably, channels in this area are sinuous to some degree. At the distal lower slope, sediments are characterized by small grain-size and low flow rate, showing stronger ability of aggregation and lateral migration but less erosion. Under this circumstance, unconfined channel systems would dominate. These channel systems are characterized by highly meandering channels which become less sinuous or even straight as sediment transportation carries on and lateral migration ability decreases. This phenomenon has been shown in modern sea-floor fans. For example, in the Zaire fan, the average curvature decreases from 1.7 to less than 1.1 as the water depth increases from 3,300-4,100 $\mathrm{m}$ to 4,100 4,800 m (Babonneau et al, 2002).

In the vertical direction, a single channel system contains a set of evolutional channel complexes as a result of sealevel fluctuation and sediment supply rate changes (Fig. 8). This vertical evolution is much more obvious especially in the semi-confined enveloped channel systems that will be further discussed below. During the early stage of channel development, a large amount of sediments at high flow rate have strong erosion ability, tending to form incised channel complexes. Channel systems, as a transportation path, are primarily filled with debris flow, collapsed and passing sediments with subsidiary incised channel complexes. During the middle stage, sediment supply is still sufficient but the flow rate decreases, resulting in a decrease of incision exceeded by an increase of sedimentation. Enveloped channel complexes are the primary sedimentary units in this stage. During the late stage, sediment supply decreases as sea-level rises under non-sudden-event conditions. Consequently, there only develop a small number of enveloped channel complexes or even isolated mud-filled single channels.

It is important to notice that the evolutions cited above are not absolute processes, because internal patterns of channel systems are determined by many factors. For example, confined channel systems could also exist mid-fan if the slope is large enough. Similarly, large scale channels could also develop within highstand system tracts if there is sufficient sediment supply caused by events such as earthquakes, tropical cyclones and convulsive tsunamis, etc (Shanmugam, 2008).

\section{Conclusions}

By using 3-D high frequency seismic data from the shallow layers in a deep-water area of the Niger Delta, the reservoir architectures of deep-water turbidite channels

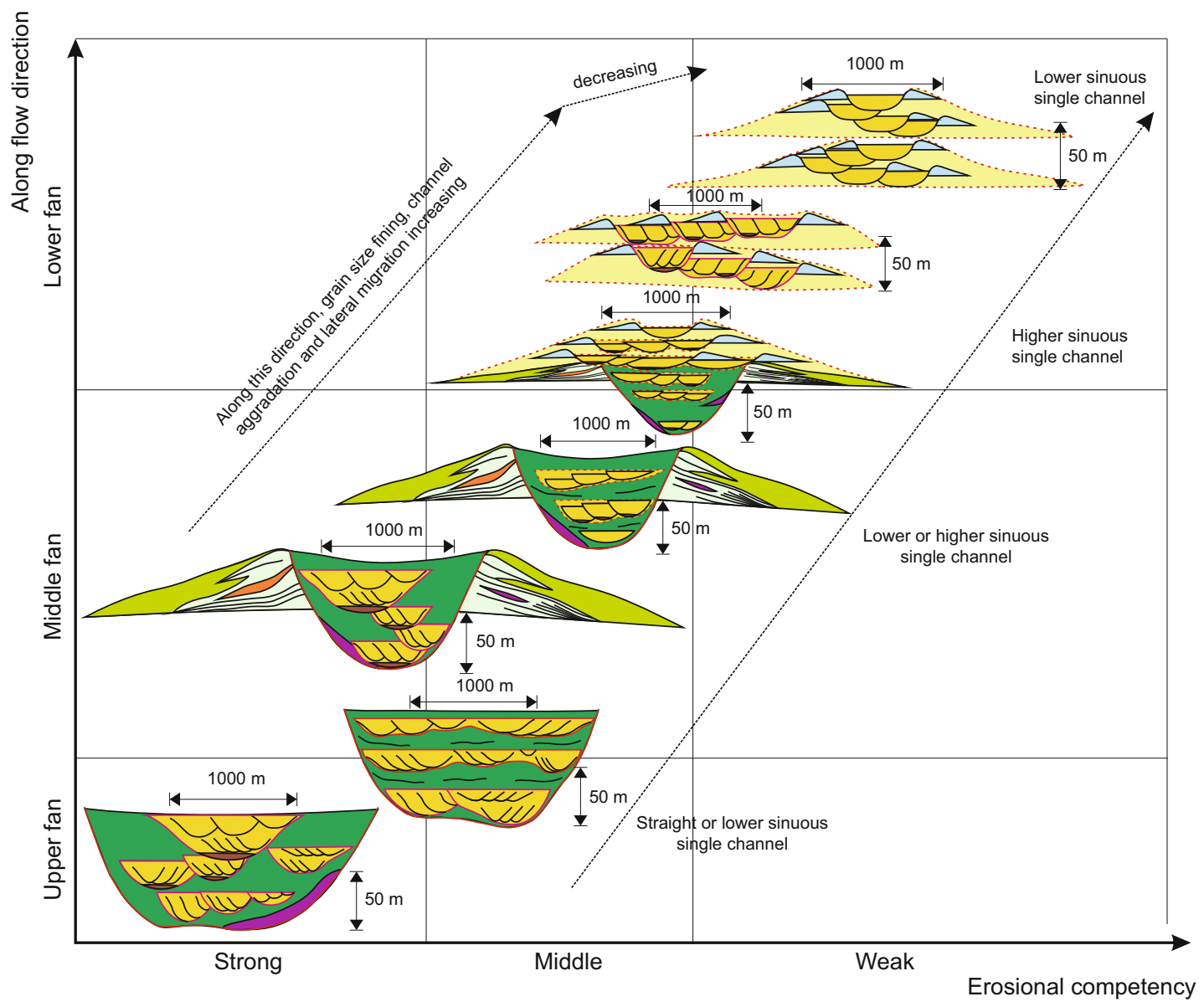

Fig. 7 Plane evolutionary trend along channel systems 


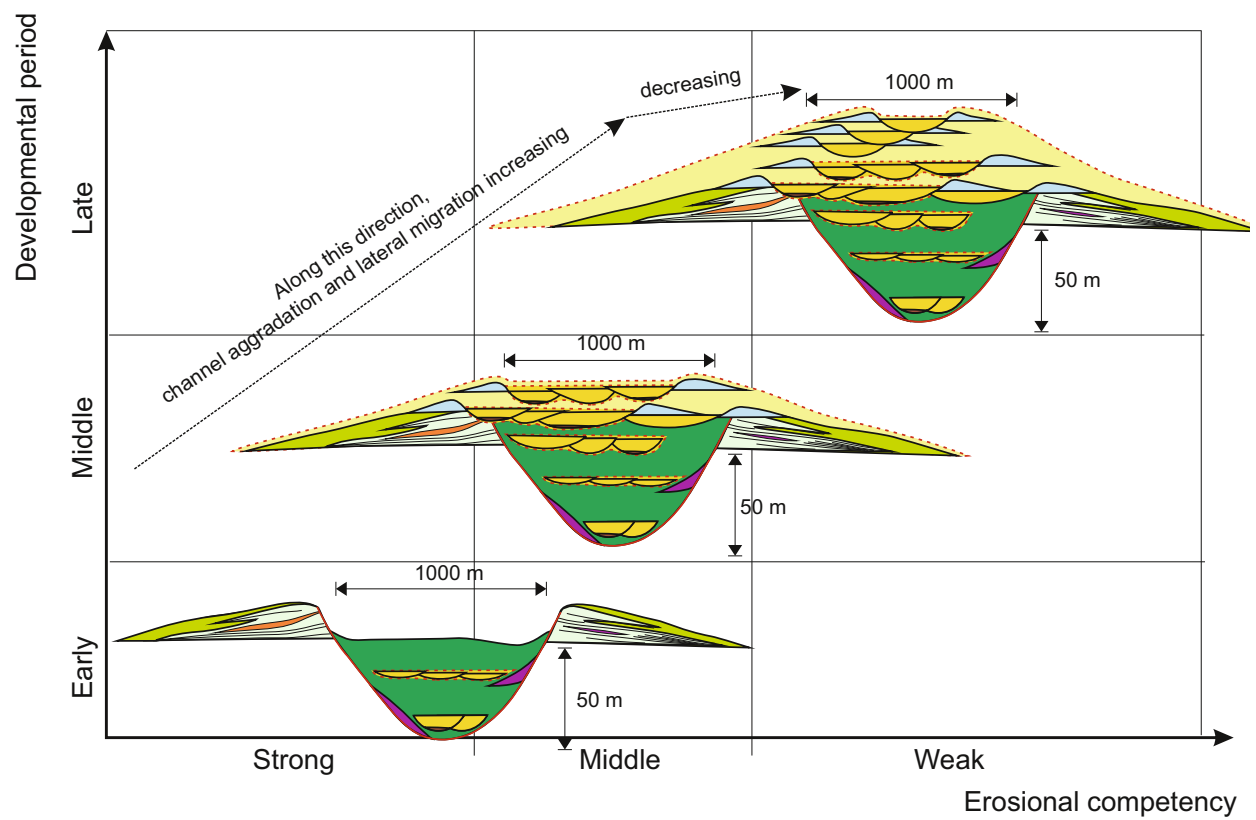

Fig. 8 Vertical (or internal) evolutionary trend of semi-confined enveloped channel systems

in West Africa are established. Channel systems can be classified into three major categories; confined, semi-confined and unconfined. The boundaries of both confined and semiconfined systems are obvious interfaces of large-scale incised valleys, but large scale wedge-shape natural levees only develop along the valley flanks of semi-confined systems. There are two kinds of channel complexes developed in channel systems, namely incised channel complexes and enveloped channel complexes. Incised channel complexes are characterized by small-scale incised valleys containing multiple single channels. Enveloped channel complexes are without incised valleys bounded by an enveloping line of multiple single channels. Accordingly, channel systems could further be classified into six subgroups. Geological factors exert impacts of different levels on the architecture of the turbidite channels in different sedimentary systems or even within the same system.

Although the internal patterns of channel systems are controlled by multiple factors, they still exhibit a spatial evolutionary trend. In planar view, the upper-fan is dominated by confined channel systems as a transport path of sediments, filled with large amount of debris flow, collapsed sediments and locally developed straight or braided channels. The middle-fan is mainly composed of semi-confined channel systems containing a large number of curved incised or enveloped channel complexes with local distribution of debris flow, collapsed and passing sediments. Unconfined channel systems mainly exist in the lower-fan areas, characterized by meandering channels which become less curved or even straight as sediment transportation continues. Vertically, incision is the primary process during the early development stage of channel systems, resulting in large amount of debris flow, collapsed and passing sediments and incised channel complexes. During the middle stage, enveloped channel complexes develop because deposition exceeds erosion. Sediment supply decreases dramatically in the late stage, leading to the development of a small number of enveloped channel complexes or isolated mud-filled single channels.

\section{Acknowledgements}

The authors would like to acknowledge with whom we had the honor and pleasure to work with, and learn from, during our research process. These people include, but are not limited to, Hu Guangyi, Sun Lichun, Zhao Pengfei and Li Yan from China National Offshore Oil Company. This work is supported by Open Fund (PLC201203) of State Key Laboratory of Oil and Gas Reservoir Geology and Exploitation (Chengdu University of Technology), National Science and Technology Major Project (2011ZX05030005), and Major Project of Education Department in Sichuan Province (13ZA0177).

\section{References}

Adeogba A A, McHargue T R and Graham S A. Transient fan architecture and depositional controls from near-surface 3-D seismic data, Niger Delta continental slope. AAPG Bulletin. 2005. 89(5): 627-643

Babonneau N, Savoye B, Cremer M, et al. Morphology and architecture of the present canyon and channel system of the Zaire deep-sea fan. Marine and Petroleum Geology. 2002. 19(4): 445-467

Beaubouef R T. Deep-water leveed-channel complexes of the Cerro Toro Formation, Upper Cretaceous, southern Chile. AAPG Bulletin. 2004. 88(11): 1471-1500

Beaubouef R T and Friedmann S J. High-resolution seismic/sequence stratigraphic framework for the evolution of Pleistocene intra slope basins, western Gulf of Mexico: Depositional models and reservoir analogs. In: Weimer P J, Slatt R M J, Coleman N C R, et al, eds. Deep-water Reservoirs of the World: Gulf Coast Section SEPM 20th Annual Research Conference. 2000. 40-60

Chen H Q, Zhu X M, Zhang G C, et al. Seismic facies in a deepwater area of a marine faulted basin: Deepwater area of the Paleogene Lingshui Formation in the Qiongdongnan Basin. Acta Geologica Sinica (English Edition). 2012. 86(2): 473-483

Chen J W. New exploration domain for oil and gas in deep water basins. Marine Geology Letters. 2003. 19(8): 38-41 (in Chinese)

Chen W. Status and challenges of Chinese deepwater oil and gas development. Petroleum Science. 2011. 8(4): 477-484

Cohen H A and McClay K. Sedimentation and shale tectonics of the 
northwestern Niger Delta front. Marine and Petroleum Geology. 1996. 13(3): 313-328

Corbeanu R M, Soegaard K, Szerbiak R B, et al. Detailed internal architecture of a fluvial channel sandstone determined from outcrop, cores, and 3-D ground-penetrating radar: Example from the middle Cretaceous ferron sandstone, east-central Utah. AAPG Bulletin. 2001. 85(9): 1583-1608

Corredor F, Shaw J H and Bilotti F. Structural styles in the deep-water fold and thrust belts of the Niger Delta. AAPG Bulletin. 2005. 89(6): 753-780

Damuth J E. Neogene gravity tectonics and depositional processes on the deep Niger Delta continental margin. Marine and Petroleum Geology. 1994. 11(3): 321-346

Deptuck M E, Steffens G S, Barton M, et al. Architecture and evolution of upper fan channel-belts on the Niger Delta slope and in the Arabian Sea. Marine and Petroleum Geology. 2003. 20(6): 649-676

Dong D D, Wu S G, Zhang G C, et al. Rifting process and formation mechanisms of syn-rift stage prolongation in the deepwater basin, northern South China Sea. Chinese Science Bulletin. 2008. 53(23): 3715-3725

Doust H and Omatsola E. Niger Delta. In: Edwards J D and Santagrossi P A, eds. Divergent/passive margin basins. AAPG Memoir 45. 1990. 201-238

Droz L, Marsset T, Ondras H, et al. Architecture of an active mud-rich turbidite system: The Zaire Fan (Congo-Angola margin southeast Atlantic): Results from ZaAngo 1 and 2 cruises. AAPG Bulletin. 2003. 87(7): 1145-1168

Emery D and Myers K J. Sequence Stratigraphy. London: Blackwell Science Ltd. 1996. 183-185

Fugelli E M G and Olsen T R. Delineating confined slope turbidite systems offshore mid-Norway: The Cretaceous deep-marine Lysing Formation. AAPG Bulletin. 2007. 91(11): 1577-1601

Hesse R, Klaucke I, Khodabakhsh S, et al. Sandy submarine braid plains: Potential deep-water reservoirs. AAPG Bulletin. 2001. 85(8): 1499-1521

Jiang H Y, Zhao W Z, Yan C Z, et al. Review on marine petroleum resources and exploration models in the Globe. Marine Origin Petroleum Geology. 2008. 13(3): 5-10 (in Chinese)

Karner G D, Driscoll N W, McGinnis J P, et al. Tectonic significance of syn-rift sediment packages across the Gabon-Cabinda continental margin. Marine and Petroleum Geology. 1997. 14(7-8): 973-1000

Kolla V, Bourges P, Urruty J M, et al. Evolution of deep-water Tertiary sinuous channels offshore Angola (West Africa) and implications for reservoir architecture. AAPG Bulletin. 2001. 85(8): 1373-1405

Labourdette R and Jones R R. Characterization of fluvial architectural elements using a three-dimensional outcrop data set: Escanilla braided system, south-central Pyrenees, Spain. Geosphere. 2007. 3(6): 422-434

Li L, Wang Y M, Huang Z C, et al. Study on sequence stratigraphy and seismic facies in deep-water Niger Delta. Acta Sedimentologica Sinica. 2008. 26(3): 407-416 (in Chinese)

Li L, Wang Y M, Xu Q, et al. Seismic geomorphology and main controls of deep-water gravity flow sedimentary process on the slope of the northern South China Sea. Science in China (Earth Sciences). 2012. 55(5): 747-757

Li L, Wang Y M, Zhang L M, et al. Confined gravity flow sedimentary process and its impact on the lower continental slope, Niger Delta. Science in China (Earth Sciences). 2010. 53(8): 1169-1175

Lü M, Wang Y and Chen Y. A discussion on origins of submarine fan deposition model and its exploration significance in Nigeria deepwater area. China Offshore Oil and Gas. 2008. 20(4): 275-282 (in Chinese)

Martin J, Cantelli A, Paola C, et al. Quantitative modeling of the evolution and geometry of incised valleys. Journal of Sedimentary Research. 2011. 81(1): 64-79

Moscardelli L, Wood L and Mann P. Mass-transport complexes and associated processes in the offshore area of Trinidad and Venezuela. AAPG Bulletin. 2006. 90(7): 1059-1088

Piper D J W and Normark W R. Sandy fans-from Amazon to Hueneme and beyond. AAPG Bulletin. 2001. 85(8): 1407-1438

Pyles D R, Jennette D C, Tomasso M, et al. Concepts learned from a 3D outcrop of a sinuous slope channel complex: Beacon channel complex, Brushy Canyon Formation, West Texas, U.S.A. Journal of Sedimentary Research. 2010. 80(1): 67-96

Saller A H, Noah J T, Ruzuar A P, et al. Linked lowstand delta to basinfloor fan deposition, offshore Indonesia: An analog for deep-water reservoir systems. AAPG Bulletin. 2004. 88(1): 21-46

Samuel A, Kneller B, Raslan S, et al. Prolific deep-marine slope channels of the Nile Delta, Egypt. AAPG Bulletin. 2003. 87(4): 541-560

Shanmugam G. The constructive functions of tropical cyclones and tsunamis on deep-water sand deposition during sea level highstand: Implications for petroleum exploration. AAPG Bulletin. 2008. 92(4): 443-471

Shao L, Li X J, Geng J H, et al. Deep water bottom current deposition in the northern South China Sea. Science in China (Earth Sciences). 2007. 50(7): 1060-1066

Shepard F P and Emery K O. Congo submarine canyon and fan valley. AAPG Bulletin. 1973. 57(9): 1679-1691

Short K C and Stauble A J. Outline of geology of Niger Delta. AAPG Bulletin. 1967. 51(5): 761-799

Slatt R M. Stratigraphic Reservoir Characterization for Petroleum Geologists, Geophysicists, and Engineers. Elsevier. 2006. 359-362

Stow D A V, Reading H G and Collinson J D. Deep seas. In: Reading H G. Sedimentary Environments: Processes, Facies and Stratigraphy (3rd Edition). Oxford: Blackwell Science. 1996. 395-453

Stow D A V and Johansson M. Deep-water massive sands: nature, origin and hydrocarbon implications. Marine and Petroleum Geology. 2000. 17(2): 145-174

Viana A, Figueiredo A, Faugeres J C, et al. The Sao Tomé deepsea turbidite system (southern Brazil Basin): Cenozoic seismic stratigraphy and sedimentary processes. AAPG Bulletin. 2003. 87(5): 873-894

Wang Y F, Wang Y M, Xu Q, et al. The early-middle Miocene submarine fan system in the Pearl River Mouth Basin, South China Sea. Petroleum Science. 2012. 9(1): 1-9

Wang Y M, Wang H R, Qiu Y, et al. Process of dynamics and its response of deep-water sedimentation. Acta Sedimentologica Sinica. 2007. 25(4): 495-504 (in Chinese)

Weimer P. Sequence stratigraphy of the Mississippi fan (PlioPleistocene), Gulf of Mexico. Geo-Marine Letters. 1989. 9(4): 185272

Wood L J and Mize-Spansky K L. Quantitative seismic geomorphology of a Quaternary leveed-channel system, offshore eastern Trinidad and Tobago, northeastern South America. AAPG Bulletin. 2009. 93(1): 101-125

Wu S G, Hang Q H, Ma Y B, et al. Petroleum system in deepwater basins of the Northern South China Sea. Journal of Earth Science. 2009. 20(1): 124-135

Xu J L, Liu L F, Wang G W, et al. Geophysical methods for the study of sedimentary cycles. Petroleum Science. 2009. 6(3): 259-265

Zhu W L, Zhong K, Li Y C, et al. Characteristics of hydrocarbon accumulation and exploration potential of the northern South China Sea deepwater basins. Chinese Science Bulletin. 2012. 57(24): 31213129 